\title{
AN INVESTIGATION OF GENERAL ANAESTHESIA AND HYPERPYREXIA IN CHICKENS
}

\author{
M. G. Viguera, M.D., AND
}

A. W. CoNN, M.D., B.SC. (MED.), F.R.C.P.(C)

HYPERPYREXIA is a rare complication of general anaesthesia. The occurrence and severity of this condition has been emphasized in recent reports in the literature. $^{1-9}$ The aetiology of hyperpyrexia when associated with anaesthesia and surgery is unknown. ${ }^{8} \mathrm{~A}$ variety of causes have been suggested. One obvious one is the injection of pyrogens or infected material, but this mechanism has been proven in only one case. ${ }^{10}$ Other possible mechanisms include uncoupling of oxidative phosphorylation in the cell, either by the action of anaesthetic agents or by ancillary drugs; ${ }^{25}$ the development by the liver of abnormal enzymes in response to drugs; and interference with transmitter substances in the temperatureregulating areas of the hypothalmus.

In hyperpyrexia associated with anaesthesia and surgery, the outstanding clinical finding is the onset of generalized muscle rigidity preceding the rise in body temperature. In patients receiving succinylcholine, rigidity developed immediately following the administration of the drug..$^{-5,5} 8$ In the absence of succinylcholine, the onset of rigidity was more gradual. ${ }^{5,7}$ The rise in temperature follows the increased heat production that occurs with generalized skeletal muscle hypertonicity.

\section{Purpose and Method of the Study}

The present investigation was designed to reproduce in animals the outstanding clinical features of this condition (hyperthermia and muscle rigidity) during general anaesthesia. In order to produce hyperthermia, it was decided to use 2:4 dinitrophenol. This drug was selected because it is known to increase the rate of tissue metabolism by interrupting the coupling of oxidation and phosphorylation. Aerobic oxidation results in the generation of heat rather than in the formation of energy-rich phosphates. Heat production greatly exceeds heat loss so that fatal hyperthermia may result.11

In order to study muscle rigidity, chickens were selected because they normally react to succinylcholine with a sustained generalized muscular contraction. It has been stated that chickens do not tolerate inhalation anaesthesia, ${ }^{12,13}$ and therefore a suitable technique for the administration of general anaesthesia had to be developed. Halothane, nitrous oxide, and oxygen were used because this anaesthetic combination had been used in many of the reported cases.

\footnotetext{
-From the Research Institute, Department of Anaesthesia, Hospital for Sick Children, Toronto, Ontario.
} 


\section{Anaesthetrc Technique}

The anaesthetic equipment used is shown in Figure 1.

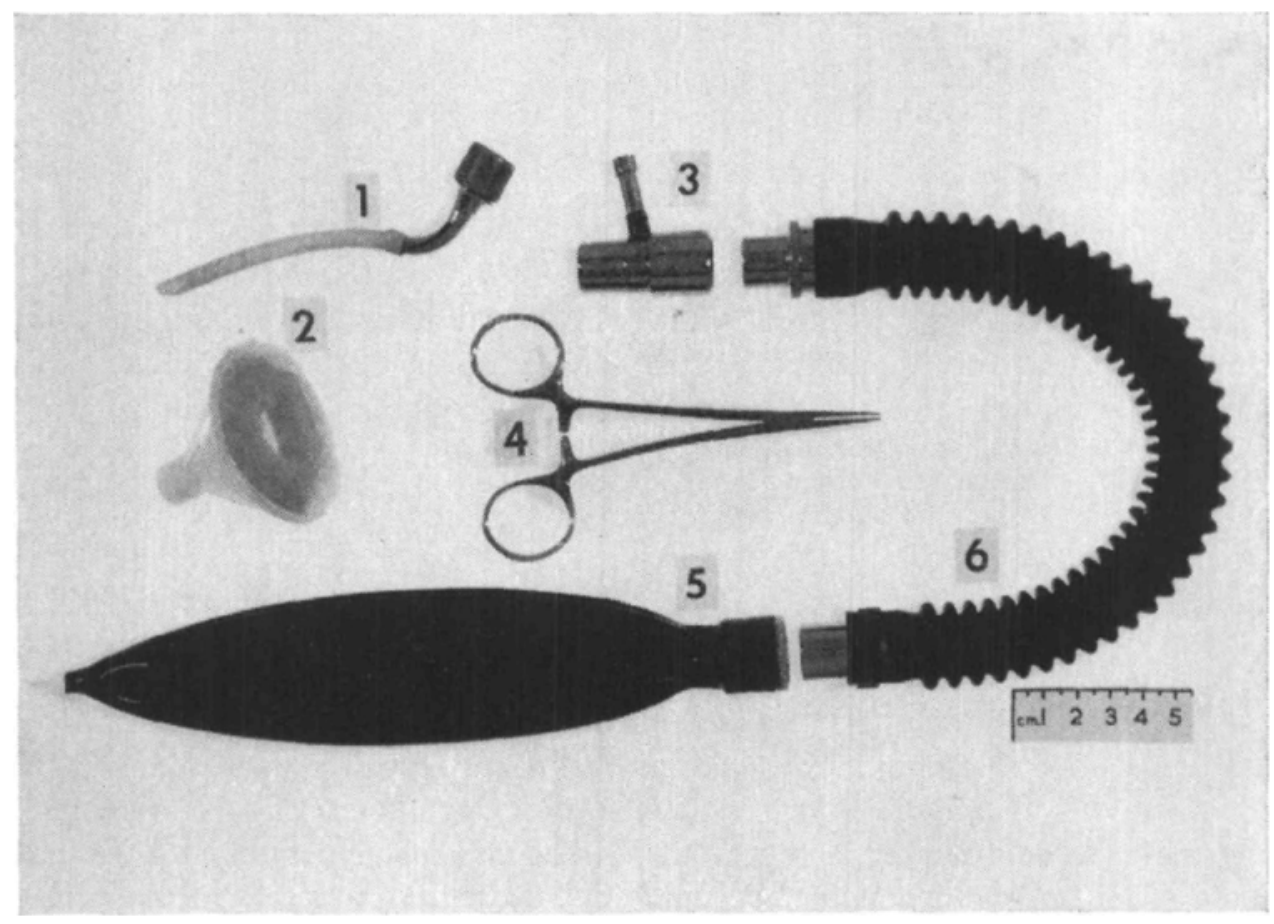

Figune 1. (1) Endotracheal tube $4.5 \mathrm{~mm}$. (2) Plastic cone-like mask with rubber foam. (3) T-piece. (4) Haemostat. (5) Bag. (6) Corrugated tube.

Induction. Inhalation induction was carried out with $\mathrm{N}_{2} \mathrm{O}-\mathrm{O}_{2}(2: 2 \mathrm{~L}$.) and halothane ( $4 \%$ for approximately three minutes). At this time the chicken was deeply anaesthetized and endotracheal intubation was performed in the following manner. A mosquito forceps was used to pull the tongue out, bringing the glottis into view. The endotracheal tube could then be introduced under direct vision, without using a laryngoscope. The tube was then fixed in place with masking tape and connected to a T-piece.

Maintenance. A satisfactory dose of halothane was found to be 1 to 1.5 per cent. Following the administration of succinylcholine, respiration was controlled either manually or with a Bird Mark VIII ventilator for as long as three hours. Total elapsed anaesthetic time in some cases was as long as six hours.

After 15 to 20 minutes of anaesthesia, thick bronchial secretions accumulated and occasionally completely blocked the endotracheal tube. Therefore at regular intervals an $8 \mathrm{Fr}$. plastic suction catheter was passed through the endotrachael tube to remove secretions and assure a patent airway.

Emergence. When halothane and nitrous oxide were discontinued the chickens regained full consciousness in approximately five to ffteen minutes. In our experience chickens tolerated inhalation anaesthesia very well provided a clear airway and adequate ventilation were maintained. 


\section{Expermamental Method}

Using fifteen chickens, thirty experiments were carried out. The animals were weighed and then atropine $(0.1 \mathrm{mg}$.) was administered intramuscularly. Rectal temperature was monitored throughout the procedure with a Yellow Springs telethermometer. Three groups of experiments were performed.

Group I. Ten chickens were anaesthetized for four hours with $\mathrm{N}_{2} \mathrm{O}-\mathrm{O}_{2}$ (2:2 L.) and halothane. Five of them were allowed to breathe spontaneously and five had ventilation controlled with a Bird Mark VIII ventilator. Every hour, venous blood samples were taken from wing veins. Determination of $\mathrm{pH}$ and $\mathrm{P}_{\mathrm{CO}_{2}}$ were performed using the Astrup microtechnique. In the first hour, sample determinations of $\mathrm{P}_{\mathrm{Oo}_{2}}, \mathrm{pH}, \mathrm{Na}, \mathrm{Cl}$ and haemoglobin were carried out (Table $\mathrm{I}$ ). On subsequent samples, only $\mathrm{P}_{\mathrm{CO}_{2}}$ and $\mathrm{pH}$ determinations were performed.

During spontaneous respiration, there was a steady rise in venous $\mathrm{P}_{\mathrm{co}_{2}}$. In no case was the $\mathrm{P}_{\mathrm{OO}_{2}}$ allowed to exceed the initial value by more than 30 per cent.

TABLE I

Acid-base Balance of Venous Blood

\begin{tabular}{lc}
\hline \hline & Normal values for chicken \\
\hline $\mathrm{Pco}_{2}$ (mm. Hg) & 26 \\
$\mathrm{pH}$ H & 7.54 \\
$\mathrm{Na}(\mathrm{mEq} . / \mathrm{L})$. & 154 \\
$\mathrm{Cl}$ (mEq./L.) & 117 \\
\hline
\end{tabular}

Normal values for venous $\mathrm{P}_{\mathrm{CO}_{2}}$ could be maintained with controlled ventilation.

The rectal temperature decreased steadily throughout each experiment. At the end of four hours, the average fall in temperature was $3^{\circ} \mathrm{F}$.

Group II. Ten chickens were anaesthetized in this group. Half an hour after the induction of anaesthesia, succinylcholine was given intramuscularly (1 mg./ kg.). Respiration was controlled until adequate spontaneous ventilation had resumed. The neuromuscular effects of succinylcholine were monitored with a nerve stimulator attached with subcutaneous needles to one of the wings. The fall in temperature was identical with that observed in Group I.

Group III. Ten chickens were anaesthetized in this group. Half an hour after induction of anaesthesia, 2:4 dinitrophenol was given $(10 \mathrm{mg} . / \mathrm{kg}$.). The rectal temperature increased an average of $2^{\circ} \mathrm{F}$. within 3 hours. Subsequently, the temperature gradually fell to its initial value.

\section{Results}

In Group I the administration of atropine, nitrous oxide, and halothane did not produce a rise in temperature in any of the ten chickens.

In Group II, in addition to general anaesthesia, succinylcholine was given. The chickens developed a generalized muscle rigidity that lasted for approximately half an hour. Nevertheless, none of them developed a rise in temperature.

In Group III, in addition to general anaesthesia, dinitrophenol was given. A 
transient moderate rise in temperature was observed. The rise in temperature was accompanied by hyperventilation, but no muscular rigidity was observed.

\section{Concluston}

Hyperthermia and generalized muscle rigidity were produced in chickens during general anaesthesia. The presence of muscle hypertonicity subsequent to succinylcholine administration was not followed by a rise in temperature. Moderate rise in temperature induced by dinitrophenol did not produce muscle rigidity. The clinical syndrome of hypertonicity and hyperpyrexia under general anaesthesia could not be reproduced using the technique outlined.

\section{RÉsUMÉ}

On a produit de l'hyperthermie et de la rigidité musculaire généralisée chez des poulets durant l’anesthésie générale. L'hypertonicité musculaire consécutive à l'administration de succinylcholine n'a pas été suivie d'élévation de température. Une élévation modérée de la temperature provoquée par le dinitrophénol n’a pas produit de rigidité musculaire. Le syndrome clinique dhypertonicité et dhyperthermie sous anesthésie générale pourrait être reproduit en utilisant la technique décrite.

\section{REFERENCES}

1. Cullen, W. G. Malignant Hyperpyrexia during General Anaesthesia: A Report of Two Cases. Canad. Anaesth. Soc. J. 13: 437 (1966).

2. Davies, L. E. \& Graves, H. B. Hyperpyrexia and Death Associated with General Anaesthesia. Canad. Anaesth. Soc. J. 13: 447 (1966).

3. Hogk, S. \& Rerwick, W. Hyperpyrexia during Anaesthesia. Canad. Anaesth. Soc. J. 13: 429 (1966).

4. LAvore, G. Hyperpyrexia during General Anaesthesia: A Case Report. Canad. Anaesth. Soc. J. 13: 444 (1966).

5. Relton, J. E. S.; Creighton, R. E.; Johnson, A. E.; Pelton, D. A.; \& Conn, A. W. Hyperpyrexia in Association with General Anaesthesia. Canad. Anaesth. Soc. J. 13: 419 (1966).

6. Rutrue, L. D., ed. Case Report No. 247: Death Occurred in the Operating Room following Extreme Hyperthermia during an Elective Cholecystectomy. Am.Soc.Anaesth. Newsletter. 26: 21 (1962).

7. Samman, L. J.; HaraAd, E. S.; \& Egen, E. I. Hyperthermia during Anesthesia. J.A.M.A. 190: 1029 (1964).

8. Thur, W. H.; Davenpont, H. T. Hyperpyrexia Associated with Succinylcholine-induced Muscle Rigidity: A Case Report. Canad. Anaesth. Soc. J. 13: 425 (1966).

9. Wilson, R. D.; Nichols, R. J.; Dent, T. E.; \& Allen, C. R. Disturbances of Oxidative Phosphorylation Mechanism as a Possible Etiology Factor in Sudden Unexplained Hyperthermia Occurring during Anesthesia. Anesthesiology. 27: 231 (1966).

10. ModerL, J. H. Septicimia as a Cause of Immediate Postoperative Hyperthermia. Anesthesiology. 27: 329 (1966).

11. Goodman, L. S. \& Gllman, A. The Pharmacological Basis of Therapeutics. Macmillan (1965), pp. 1482-83.

12. Gandal, C. P. Satisfactory General Anaesthesia in Birds. J.Am.Vet.M.A. 128: 332 (1956).

13. Lumb, J. W. Small Animal Anaesthesia. Philadelphia: Leal and Faber (1963), pp. 27479.

14. Handbook of Respiration. Philadelphia: Saunders, p. 93.

15. Burforo, G. E. Hyperthermia following Anesthesia: Consideration of Control of Body Temperature during Anesthesia. Anesthesiology. 1: 208 (1940). 